\title{
P \\ Bad company. The indirect effect of differences in corporate governance in the pension plan industry
}

\author{
Abinzano I., Muga L. and Santamaría R. \\ Public University of Navarre and Institute for Advanced Research in Business and Economics \\ (INARBE) \\ July, 2017
}

\begin{abstract}
This paper analyses the role played by pension plan governance structure and how it impacts on plan fees and plan performance. The results clearly show that fees decrease significantly and performance improves when pension plan governance structures permit full alignment of interests and allow greater capacity for the decision-makers to monitor and discipline the managers. It is also observed that companies managing both employee and individual funds, tend to exploit differences in the internal corporate governance mechanisms of each type of plan in order to nurture employer-sponsored plans at the expense of individual plans. These results suggest that internal corporate governance mechanisms allowing closer alignment with the interests of participants would be preferable to focusing exclusively on setting the minimum proportion of independent directors.
\end{abstract}

\section{Keywords}

Pension Plan Governance; Bargaining Power; Fees; Performance

\section{Acknowlegements:}

Financial support from the Spanish Ministry of Economy and Competitiveness, Project ECO2016-77631-R and Fundación Caja Navarra FUNCAN-07445 are gratefully acknowledged.. 


\title{
Bad company. The indirect effect of differences in corporate governance in the pension plan industry
}

\begin{abstract}
This paper analyses the role played by pension plan governance structure and how it impacts on plan fees and plan performance. The results clearly show that fees decrease significantly and performance improves when pension plan governance structures permit full alignment of interests and allow greater capacity for the decision-makers to monitor and discipline the managers. It is also observed that companies managing both employee and individual funds, tend to exploit differences in the internal corporate governance mechanisms of each type of plan in order to nurture employer-sponsored plans at the expense of individual plans. These results suggest that internal corporate governance mechanisms allowing closer alignment with the interests of participants would be preferable to focusing exclusively on setting the minimum proportion of independent directors.
\end{abstract}

\section{Keywords}

Pension Plan Governance; Bargaining Power; Fees; Performance. 


\section{Bad company. The indirect effect of differences in corporate governance in the pension plan industry}

\section{1.-Introduction}

Fund governance can be exercised through internal mechanisms (the board) or external mechanisms (fund inflows) (see Khorana, 1996). Analysis of the role of internal mechanisms has focused primarily on the impact of regulations to ensure a minimum percentage of independent directors and on the independence of the board chair, and, while the empirical evidence on the subject tends to be favourable, it is not entirely unanimous (see, among others, Tufano and Servick, 1997;Mahoney,2004; Ingle et al., 2004,Palmiter, 2006;Hoffman et al., 2008, Ferris and Yan, 2007;Chen and Huang, 2011;Ding and Wermers, 2012; or Tan and Cam, 2015).

The literature also casts some doubt on the importance of the role played by external mechanisms, having shown that it depends, among other variables, on investor type. There is, indeed, evidence to show that institutional investors exercise market governance by withdrawing assets under management (Del Guercio and Tkac, 2002; or Goyal and Wahal, 2008), whereas retail mutual fund flows are much less responsive (Evans and Fahlenbrach, 2012). James and Karceski (2006), placing the emphasis on differences in investor monitoring capacity, show that retail funds perform significantly worse than institutional funds, before and after adjusting for risk and expenses. In a study dealing with the analysis of individual investment funds, Ivkovic and Weisbenner (2009) demonstrate the influence of tax issues on investment decisions, and show that individuals' fund-level inflows and outflows are performance sensitive, but in different ways. In short, this body of work reveals that certain elements, particularly those linked to investor type, can have a clear impact on the effectiveness of external factors as fund governance mechanisms.

It is worth considering whether the driving forces behind investors as a fund governance mechanism may be not just performance sensitivity, and motivation or sophistication in 
monitoring, but also the power to bargain ${ }^{1}$ with the management and custody firm, which varies with, among other things, supply- and demand-market structures. Let us emphasize, at this point, however, that the demand pattern may be heavily determined by the pension plan governance structure, thus linking internal and external plan governance mechanisms.

The existence of corporate government mechanisms that enable the alignment of investor and fund manager interests and facilitate collective decision-making can result in a de facto increase in demand concentration which helps to protect investors' interests. The absence of such mechanisms leaves investors with no alternative except to exercise their individual exit rights.

The Spanish pension plan industry provides an excellent framework for the empirical analysis of this interesting issue because of its unique institutional environment, which accommodates two main pension plan types ${ }^{2}$ (individual and employer-sponsored) which contrast sharply in terms of governance structure. In employer-sponsored plans, the fund oversight committee ("Control Committee") has the competence not only to determine fund characteristics, but also to select the management firm and custody firm. The promoter (which is the employer firm) has $50 \%$ of the votes on the fund Control Committee, while the remainder is shared among participants and beneficiaries ${ }^{3}$. Thus, investors' disperse individual interests are represented collectively by a single decisionmaking body (Control Committee) with interests aligned to their own, which substantially increases their concentration in practical terms. This clearly boosts the decision-maker's power to bargain with the management firm, when laying out the terms of the contract,

\footnotetext{
1 The importance of bargaining power has come to light in the analysis of various service costs (see, among others, Castarela et al., 2004, Roth, 2006, Kwak et al., 2006 and $\mathrm{Wu}$ and $\mathrm{Wu}, 2007)$.

2 In Spain there are two types of private pension plans: personal and occupational (employer-sponsored). Personal pension plans can be individual or associated. An associated pension plan is one that is founded by an association or union, where all participants must be associates, members, or affiliates of the promoting body. For these specific characteristics, in this study we focus on individual and occupational plans only. The associated pension plans most often found in Spain are those promoted by trade unions.

3 This percentage is established at plan level, given that every plan has a Control Committee. If the fund has only one plan, the plan Control Committee becomes the fund Control Committee and the described situation ensues. Otherwise, the fund Control Committee will maintain the representational distribution of the various plans under its administration. Note also, however, that the shares can be adjusted upon a collective bargaining agreement, albeit within certain legal limits.
} 
monitoring performance, and negotiating fees and other expenses associated with the plan.

In the case of individual plans, however, it is the promoter, which is a financial institution, that selects a management firm and custody firm, without any direct representation of the participants or beneficiaries in any of the governing bodies. In fact, there is generally no Control Committee ${ }^{4}$. The only option open to a participant who is unhappy with plan performance or the levels of fees or other expenses, is to exercise the right of exit, that is, to withdraw the money invested in the plan and transfer it to another ${ }^{5}$.These individual decision-makers, of course, have considerably less bargaining power and monitoring capacity than is held by investors in employer-sponsored pension plans. Note, finally, that management firms do not specialize in individual or in employer-sponsored pension plans, but tend to manage both plan types ${ }^{6}$. Thus, any differences in performance, fees or expenses cannot reasonably be attributed to differences between management firms.

In this context, the first issue for analysis is whether these differences in pension plan governance structures have a relevant impact on fee setting, given the importance of the latter in the ultimate return on the investment not only for the participants, but also, of course, for the management (and custody) firm, whose main source of income it is. The second is whether the two plan types differ significantly in performance terms. As noted previously, the literature has already analysed the role of investor typology in these issues. The first novelty of this paper is that we analyse two pension plan governance structures, each offering participants a very different degree of monitoring capacity and bargaining power with which to discipline managers.

Since some management firms handle pension plans of both types (individual and employer-sponsored), we are also able to test whether this simultaneous management of

\footnotetext{
${ }^{4}$ A Control Committee is necessary only when there is more than one promoter, which is very rare in practice, given that the only promoters of this type of plan are financial institutions (banks, savings banks, insurance companies, etc.) which also usually own the management firms.

5 There also exists a type of "ombudsman" or investor advocate ("Defensor del Partícipe"), whom investors can consult if they wish to appeal against pension plan decisions.

6 The overall average percentage of management firms managing both individual and employer-sponsored plans, over the sample period (2008-2014), is 47.08\%, among which are the largest. Indeed, for the year 2014, average total assets for firms managing both types of plan is 1.6 times greater than for those specializing in one type only. When calculated in terms of the financial group to which the managing company is affiliated, the percentage reaches $64 \%$, with average fund size 1.53 greater.
} 
plans with such different governance structures has positive or negative consequences for participants or plays no role at all, either in the fee setting process or the performance of the funds under management. There exists empirical evidence, albeit not related with the impact of corporate governance structure on pension plans, supporting either a positive or a negative impact. Note, however, that this literature addresses several distinct issues and that the various studies it includes do not offer alternative explanations for the phenomenon in hand, nor are their findings strictly incompatible with each other.

Findings that might support the existence of a positive effect are those reported by Evans and Fahlenbrach (2012) in an analysis of retail-institutional mutual fund twins. According to these authors, monitoring by institutional investors results in higher yields for funds with institutional and retail class shares at the same time as for those with retail class shares only, thus providing support for a positive synergy effect on performance from sharing governance with more sophisticated investors. Given that, by virtue of the Control Committee, there is a more sophisticated decision-maker in employer-sponsored plans (Abinzano et al., 2016), the implication of the findings of Evans and Fahlembrach (2012) for the case in hand might suggest a positive effect on individual plans managed by firms handling both types of plans.

The theory of a negative effect could be supported by the findings of Gaspar et al., (2006) who report cross-fund subsidization in mutual fund families benefiting those with higher fees and higher yield and potentially attracting more cash inflow to the fund family. In the case that concerns us, the stronger pressure coming from employer-sponsored plans could lead management firms to engage in strategic behaviour and protect the interests of these plans at the expense of individual ones.

This paper makes two main contributions to the literature. Firstly, it finds significantly lower fees and better before- and after-fee performance in pension plan governance structures that permit full alignment of interests. Secondly, and more innovatively, our study finds that firms managing employer-sponsored and individual plans, each with its own governance characteristics, are incentivized to take advantage of their existing differences by engaging in cross-fund subsidization. 
The rest of the paper is organized as follows: Section 2 presents a brief description of the Spanish pension plan framework. Section 3 presents the testable hypotheses. Section 4 describes the database used in the study. Section 5 describes the methodology. Section 6 reports the main results and robustness checks and the seventh and final section discusses the main conclusions.

\section{2.-Spanish pension plan framework}

The legal and governance structure of pension plans varies across countries. As shown in Stewart and Yermo (2008), there are two types of autonomous pension funds: the institutional type (which has its own internal governing board) and the contractual type (where the governing body is usually the board of directors of the management firm). There are also mixed types. In particular, the trust, which is the legal form in Anglo-Saxon countries, has characteristics of both types.

Spanish pension funds are of the contractual type, although governance is shared with a separate oversight committee ("Control Committee"). The differences in governance structure between individual and employer-sponsored plans in Spain are inherent in their very creation. As we have already mentioned, the promoter in the case of employersponsored plans is the employer firm, which holds $50 \%$ of the votes in the Plan Control Committee, while the rest are shared among the participants and beneficiaries. When the plan is the only one in the pension fund 7 , the Plan Control Committee is the Fund Control Committee, which has the decision-making power in issues as important as determining fund characteristics and hiring (and/or firing) firms to manage and take custody of the assets of all the fund's pension plans. The objectives of this committee are very closely aligned with those of the participants, assuming, as is reasonable, that the firm's concern for its workers will not differ appreciably from its concern for itself ${ }^{8}$. A very different case is that of individual plans, however, where the promoter is a financial institution with sole

\footnotetext{
7 A pension fund comprises the combined assets of one or more pension plans. It is managed by a single company and held in custody by another. Employee pension funds contain only employer-sponsored pension plans, while personal pension funds contain only individual or associated pension plans. A given pension plan may invest in more than one pension fund.

${ }^{8}$ It must be emphasized that the employees of such firms are represented on the Control Committee through the representatives of the participants and beneficiaries.
} 
right of representation on the Control Committee. If, moreover, all the plans in the individual pension fund are from the same promoter (which is usually the case with financial institutions who will have no wish to share the organization and management of the fund with rival institutions), there is no need to set up such a Committee, and it will be the promoter's prerogative to determine the characteristics of the plan and hire firms to manage and take custody of it. Potential agency costs are therefore high. Under these conditions, the only option open to participants who, having joined the plan, find the conditions unacceptable, is to exercise their right of exit.

In Spain, the pension plan management offer is limited, because many management firms are tied to families, therefore market concentration is high. In particular, the Herfindahl indices in the year $2014^{9}$ are 1,082 for the overall pension plan market, 1,000 for the individual plan market and 1,493 for the employer-sponsored plan market. These figures paint a rather optimistic picture of actual concentration, however, since the summed market shares of the top five families are $62.28 \%$ overall, $62.65 \%$ for individual plans and $75.15 \%$ for employer-sponsored plans. In terms of numbers of plans rather than assets under management, however, the values are $43.89 \%, 34.82 \%$ and $48.04 \%$, which tells us that there is a number of small management firms offering their services and adding some competition to the market. The supply concentration level increased during the study period (2008-2014), as shown by the fact that in December 2007 the above-mentioned Herfindahl indices were 781, 744 and 1,186, respectively, and the summed market shares of the top five families amounted to $53.01 \%, 53.37 \%$ and $70.24 \%$, respectively, and $30.55 \%$, $27.65 \%$ and $32.89 \%$ in terms of numbers of plans. The higher concentration is largely due to the bank restructuring process undertaken to address the financial crisis, which led to numerous mergers and to the virtual demise of the savings banks, which were either transformed into or taken over by banks.

Measuring demand concentration is quite a complicated task, due to limited information. A few simple indicators will, nevertheless, provide an approximation. Firstly, the demand for individual plans is highly fragmented, since the key decision-maker is the individual. Thus, according to data for December 2014, the total number of participants in individual

\footnotetext{
${ }_{9}^{9}$ Data drawn from December statistics supplied by Inverco (http:// www.inverco.es/en/).
} 
plans is $7,824,182$, with an average investment of 8,198 Euros. In employer-sponsored plans, however, it is up to the Fund Control Committee to hire or replace the management (or custody) firm, thus there are as many decision-makers as there are pension funds ${ }^{10}$. On this basis, the number of decision-makers is 339, with an average investment per fund of $101,297,029$ Euros. Taking the data at plan level, which is where the option to join one fund or another lies, there are 1,324 plans with an average investment per plan of 25,936,324 Euros. In either case, it can be seen that demand is clearly more concentrated ${ }^{11}$, therefore the decision-makers will have more monitoring capacity and bargaining power in their dealings with the management firm. Note that supply concentration is high in both types of plan, but demand concentration is considerably higher in employer-sponsored plans, which have, in addition, a corporate governance mechanism that allows them to fire the management firm, thereby doubtlessly increasing their monitoring capacity and relative degree of bargaining power.

\section{3.-Testable Hypotheses}

Fama and Jensen (1983) argue that the right of exit reduces the need for other forms of governance in mutual funds. Del Guercio and Tkac (2002) show, however, that this mechanism works less well in pension plans than in mutual funds. Evans and Fahlenbrach (2012) also attenuate Fama and Jensen's (1983) claim that it depends on the adequacy of the criteria participants use to evaluate funds. Furthermore, the literature has brought to light no evidence to show that this mechanism works in the same way irrespective of investor type (see, among others, Khorana et al., 2008). Other factors that cannot be ignored are investors' monitoring capacity and their power to bargain with the management firm. Pension plan investors can, of course, effectively remove the managers from the control of their assets, but this leaves a series of questions to be answered: Does it

\footnotetext{
10 The right to exit is limited for participants in employer-sponsored plans who can redeem their shares at net asset value to invest in a pension plan that is not promoted by the employer firm, only if their employment contract has been rescinded and the plan statutes specifically allow it. The cash can also be withdrawn for personal reasons in unusual circumstances such as long-term illness or unemployment. A further option for participants in individual plans is to redeem their shares at net asset value to invest in another individual plan without any constraint.

11 Note that the remaining characteristics, particularly those relating to traded assets, are exactly the same for both types of plan, therefore no further variables that might condition the actual level of bargaining power are considered.
} 
mean the same to the management firm when right of exit is exercised by an individual pension plan participant (with an average investment of 8,198 Euros in a fund with average total assets of 63.4 million Euros in 2014) as it does when it is exercised by the Control Committee of an employer-sponsored plan with an average investment of 25.9 million Euros? Will the difference in their degree of concern over these two eventualities influence the management and custody firms in the initial fee bargaining process? Are there significant future performance gains to be made from the capacity for closer monitoring of pension plan managers and the potential threat of their dismissal if investors' expectations are not met?

These questions lead to the following null hypothesis, which we formulate separately for the total fees (management and custody fees) paid by the participant and performance.

H01: Fees are the same for employer-sponsored and individual pension plans.

H02: Performance is the same for employer-sponsored and individual pension plans.

We expect to reject the null hypothesis in both cases. In the first case, the presence of a Control Committee in employer-sponsored plans, along with the implied increase in monitoring capacity and bargaining power ${ }^{12}$, makes it possible to obtain more favourable terms, in particular, lower fees, since they are explicit in the contract and easily verifiable ex-post. Bear in mind that, as noted by Luo (2002), mutual fund fees reflect not only costrelated variables but also the exploitation of the fund's market power. If the pension plan has a corporate governance structure that endows it with a high degree of bargaining power and monitoring capacity, it can compensate for the market power of the management firm and reduce its fee burden. We therefore expect to find evidence to support the alternative hypothesis:

HA1: The fees to investors are lower in employer-sponsored plans than in individual plans.

In the second case, even without the sophistication shown by the traditional institutional investor (banks, mutual funds, pension plans, insurance firms, etc.), closer monitoring and

\footnotetext{
12 The effects on fees and performance cannot be attributed directly to any of the consequences of corporate governance differences. We are grateful to an anonymous referee for indicating up the need to clarify this point.
} 
alignment of interests, along with the effects of the potential threat of exit will prompt the management firm to protect investors' interests and try to maximize fund performance. This will enable us to find evidence to support the alternative hypothesis:

HA2: Employer-sponsored plans present higher performance indicators than individual plans.

As well as in the direct effect of differences in pension plan governance structures on respective fees and performance, we are interested in any possible indirect effects arising in the cases of management firms handling both employer-sponsored and individual pension plans. With respect to this, there exist research findings on various issues relating to the mutual fund sector that would equally support either a positive or a negative effect. The findings of Evans and Fahlenbrach (2012), for example, would support arguments for the presence of positive effects. These authors compare strictly retail mutual funds with others offering both retail and institutional plan options (twins). Their results show that retail funds with institutional twins perform better than those without, and that investors in the retail twin may benefit from closer monitoring by institutional investors. They have also observed lower direct and indirect expenses in the retail funds with institutional twins than in the control group. This confirms the presence of a positive effect from monitoring, which favours the interests of institutional investors ${ }^{13}$, and, more importantly for our analysis, the presence of a positive effect in something that has no direct impact on institutional share class performance: direct and indirect retail share class expenses. Given the more sophisticated decision-making that exists in employer-sponsored plans (Abinzano et al. 2016), together with corporate governance mechanisms enabling effective monitoring of management firms, the latter might benefit from the effect generated by employer-sponsored plans when handling both types.

From their analysis of an entirely different issue, Gaspar et al. (2006) obtain findings to support arguments in favour of negative effects. In particular, these authors show that fund families transfer performance across member funds. Even more specifically, they report evidence of cross-fund "subsidization" because the funds with more value for the family over perform at the expense of those with lower value in order to maximize the

\footnotetext{
${ }^{13}$ Which includes performance, and therefore benefits both investor classes, given that institutional versions of the same fund hold virtually the same portfolios.
} 
benefits of the fund family. In the case that concerns us, the closer monitoring that takes place in employer-sponsored plans due to presence of the Control Committee generates incentives to maximize returns at the expense of individual plans, whose participants exercise only a minimal degree of monitoring while also lacking the basic tool at the disposal of the Control Committee in employer-sponsored plans: i.e., the ability to dismiss the management firm.

These considerations lead us to the following null and two alternative hypotheses, which we propose for fees and performance jointly:

H03: Management of employer-sponsored and individual pension plans by the same firm has no impact on fees and performance of these plans.

If a positive effect is accepted to derive from the supervision and discipline exercised by the Control Committee of employer-sponsored funds, we must expect to observe positive externalities which cannot be appropriated by the employer-sponsored plan investors, but which benefit the individual plan investors. This might be observed both in fees, which are a highly visible, objective and verifiable variable, and in performance, which, while relevant, is more subject to measurement and interpretation. Performance also encompasses both explicit elements and hidden costs and is influenced by them. This would provide us with evidence to support the alternative hypothesis HA3.1.

HA3.1: Management of employer-sponsored and individual pension plans by the same firm has a positive impact on Fees and Performance in individual plans..

However, going along with the prevailing arguments for strategic behaviour on the part of management firms, as suggested by the findings of Gaspar et al. (2006), will lead us to expect to find parasitism of individual plans by employer-sponsored plans due to corporate governance differences which imply lower bargaining power and monitoring capacity in individual plans. Again, signs of "subsidization" might be observed both in fees and performance, thus providing evidence to support the alternative hypothesis HA3.2. 
HA3.2: Management of employer-sponsored and individual pension plans by the same firm has a negative impact on Fees and Performance in individual plans.

\section{4.- Database}

The data base for the analysis of the above issues includes annual data for all Spanish individual and employer-sponsored defined-contribution private pension plans ${ }^{14}$ over the period from 2008 to 2014 according to data supplied by the Spanish General Insurance Authority (Dirección General de Seguros y Fondos de Pensiones, DGS) and thus, the database is free of survivorship bias. For the sake of homogeneity in the comparison of plan performance, this study focuses on equity plans fulfilling the above characteristics. We are led in this respect by the need to use a basic performance measure, namely, the Sharpe ratio, due to data availability constraints.

These data comprise for each plan: the year; name of pension fund; name of pension plan; custodian firm; financial group (family) to which the custodian firm is affiliated; management firm; financial group to which the management firm is affiliated; the past 1 , 5,10 , and 15-year returns; the variance of the returns of the plan; the custodian fee; the management fee; the number of fund participants; and assets under fund management in Euros.

Fees include the yearly total costs of the plan (management fees plus custody fees). There are other costs, some of them known as hidden fees (fund trading costs, trade market prices impact, soft-dollar trading costs, etc., see, among others, Hutcheson, 2007 or Haslem, 2012), for which we have no data. Our intuition suggests that if effects are found on fees that are known to the public, observable in trading reports and verifiable ex-post, they are even more likely to occur among hidden costs where are they harder to detect and verify. These hidden costs would play a role in the performance analysis, to the extent that the higher the hidden costs the lower fund returns.

\footnotetext{
14 In the Spanish framework there are seven types of plan: 1.1: employer-sponsored with defined benefit; 1.2: employer-sponsored with defined contribution; 1.3: hybrid employer-sponsored; 2.1: associated with defined benefit; 2.2: associated with defined contribution; 2.3: hybrid associated; and 3.2: individual. The "associated" plans are founded by an association or union, where all participants must be associates, members, or affiliates of the promoting body.
} 
In addition to the above information, data from the Statistical Bulletin of the Bank of Spain were used. Specifically, the risk free rate was estimated from the interest rate for treasury bills (outright spot transactions up to 3 months). Performance was proxied with the Sharpe Ratio, both before and after fees, which measures contemporaneous risk-adjusted pension plan performance. Although overall market performance and stock characteristics measured by the alpha coefficient are ignored in the measurement of the Sharpe Ratio, making it only a noisy measure of fund managers' skills, it has the advantage of being more directly observable to some investors than alpha and has a more noticeable influence on their decisions (see Cumming et al., 2016). Furthermore, given that the DGS database contains only annual return data for pension plans during the period of analysis (2008 to 2014), this is a reasonable solution to the problem of estimating factorial models with a limited number of time series observations. This measure is also used, with acknowledgement of its shortcomings, by Antolin (2008) to analyse aggregate investment performance by country on a risk-adjusted basis using relatively standard investment performance measures; by Chen and Huang (2011) to analyse the relationship between mutual fund governance mechanisms and contemporaneous performance ${ }^{15}$; and in the robustness checks presented by Cumming et al. (2016), who show that their results under the Sharpe Ratio performance measure are also consistent with the results obtained using alpha.

After screening for the above mentioned criteria, the sample comprises a total of 34 employer-sponsored funds with 151 plans in all, and 143 individual funds comprising 226 plans in all ${ }^{16}$. Panel A in Table 1 shows some descriptive statistics for the sample. The average fee across the sample plans is $1.226 \%$, and clearly higher for individual plans $(1.807 \%)$ than for employer-sponsored plans $(0.468 \%)$. The average return before fees is $0.532 \%$, but the return on employer-sponsored plans $(0.790 \%)$ more than doubles that obtained by individual plans $(0.334 \%)$, and is 3.31 times higher when measured after fees ( $0.704 \%$ for employer-sponsored plans vs. $0.212 \%$ for individual plans). Clearly therefore, in the absence of further analysis, these fee and performance data appear to support the above arguments regarding the differences between the two plan types. The average

\footnotetext{
15 These authors also use the three-year Alpha for the analysis of mid-term returns.

16 The total number of plans is 415 , but missing data on some of the key variables used in the various estimations in the study reduced this figure to 377 (151 employer-sponsored and 226 individual).
} 
return variance is $13.072 \%$, and it is clearly lower in employer-sponsored plans $(6.339 \%)$ than in individual plans $(18.244 \%)$. Finally, management firm size, measured as the natural log of total assets under managed by the firm, is greater in the case of employersponsored plans ${ }^{17}$, and will therefore be included in the various estimations with a view to examining its impact.

The values in the correlation matrix are reasonable (see Panel B in Table 1), except for two cases, namely, the correlation of the dummy variable for employer-sponsored plans (Emp), and plan return variance (Var), with Fees. This is no cause for concern, however, because Fees is the dependent variable in one of the models. In the Model 1 and Model 3 where performance is the dependent variable, however, the relationship between Fees and Emp might warrant some concern, since the variable Var is not included in the estimation. Nevertheless, the conclusions hold whether Fees is included as an independent variable or not.

\section{5.-Methodology}

The first issue to be addressed is whether the differences in governance structure between employer-sponsored and individual plans have a significant impact on fee setting. Taking into account that the observed dependent variable is censored (total fees) because in Spain there is a legal maximum for both management $(2 \%)$ and custodian $(0.5 \%)$ fees, we deal with this problem by fitting a Tobit model to the data with lower censoring at zero and upper censoring at the fee cap: $2.50 \%$ for total fees ${ }^{18}$.

Model 1 takes the following form:

$$
\begin{array}{ll}
y_{i}=\alpha+\beta^{\prime} x_{i}+u_{i} & \text { if } \underline{y} \leq \alpha+\beta^{\prime} x_{i}+u_{i} \leq \bar{y} \\
y_{i}=\underline{y} & \text { if } \alpha+\beta^{\prime} x_{i}+u_{i}<\underline{y} \\
y_{i}=\bar{y} & \text { if } \alpha+\beta^{\prime} x_{i}+u_{i}>\bar{y}
\end{array}
$$

\footnotetext{
17 About the untransformed variable, average total assets under management of firms that manage employersponsored plans are 1.54 times greater than for those that manage individual plans. Importantly, recall that whereas some firms manage only one plan type, the large proportion that manage both include the largest firms, the above comparison by firm size must therefore be performed with caution.

18 Royal Decree 681/2014, dated August 1st, and effective as of October 2nd 2014, produced a change in the fee cap whereby the Maximum Management Fee was set at $1.5 \%$, but this could optionally be replaced by an annual fee of $1.2 \%$ plus $9 \%$ of net income generated. Maximum Custody Fee: $0.25 \%$ per year.
} 
where $\mathrm{y}_{\mathrm{i}}$ is the total fee decision; $\underline{y}$ is the minimum fee: (zero); $\bar{y}$ is the maximum legal fee; $\beta$ is a $k x 1$ vector of unknown parameters; $x_{i}$ is a vector of the same size containing the explanatory variables of the fee decision. These explanatory variables are a dummy variable Emp which is equal to 1 in the case of employer sponsored plans and 0 otherwise and a set of control variables. In particular, plan performance (Perf), proxied by its Sharpe Ratio $^{19}$, pension plan performance variance (Var) as a risk measure, a dummy variable (New) representing the first year of a pension plan, and the size of the management firm (SizeMgFirm), proxied by the total assets under management of the plans managed by this firm. Fixed year effects and dummy variables representing the top families (average number of plans by year $>20$ ) are also included in the estimation. To avoid potential bias resulting from simultaneity between the dependent variable, Fees, and the variables Perf, Var and SizeMgFirm, the latter are lagged by one period. For added robustness, and to take into account the high persistence in fees, we also present the results including the lag of total fees (Feeslag). Performance is included as a control variable in response to findings showing dynamic links between fees and performance (see Christoffersen, 2001). Fund risk and size of management firm also influence fee levels (see, among others, Khorana et al., 2008). Finally, New is introduced because of empirical evidence of the presence of market penetration strategies in mutual funds and individual pension plans (see Christoffersen and Musto, 2002, Muga and Santamaria, 2010 and Abinzano et al., 2016).

Model parameters are estimated by maximum likelihood, assuming that $\mathrm{u}_{\mathrm{i}}$ are normally distributed residuals with mean zero and constant standard deviation. However, the Huber/White estimator was used to compute heteroskedasticity robust standard errors for coefficients estimated.

Having analysed the effect on fees, the next issue to be examined is the effect of differences in governance structure on pension plan performance. As already stated, the performance measure is the Sharpe Ratio, calculated both before and after fees.

Model 2 is specified as follows:

${ }^{19}$ Estimated return before fees is used to neutralize the possible effect of fees on Sharpe Ratio. 
Perf $_{i t}=\alpha+\beta_{1}$ Emp $_{i}+\beta_{2}$ Fees $_{i t-1}+\beta_{3}$ SizeMgFirm $_{i t-1}+\beta_{4}$ New $_{i}+\beta_{5}$ Perfinitial $_{i}+\delta_{t}+\gamma_{k}$
$+\varepsilon_{i t}$ where the dependent variable is the performance of plan $i$, for period $t$; the main independent variable is Emp, which is equal to 1 if the plan is employer-sponsored and 0 otherwise. The rest of the independent variables are control variables: Fees and SizeMgFirm. In order to control for potential endogeneity among the plan-level explanatory variables, these variables are lagged by one period. Fees are included as a control variable to capture either a positive or a negative relationship between fees and performance, and strategic linking of management fees to investment performance (see Christoffersen, 2001). The purpose of the variable SizeMgFirm is to capture economies or diseconomies of scale (see, among others, Chen et al., 2004). A baseline performance variable (PerfInitial, year 2007) is also included to control for potential inverse causality between actual and baseline performance. Two specific effects (year $\left(\delta_{t}\right)$ and family $\left(\gamma_{k}\right)$ ) are included in the estimation in order to address the problem of omitted variables in the model specification and to control for any shocks that might affect performance. The estimation is repeated including the dummy variable New. Although the need for its inclusion is less obvious in the performance analysis than in the fee analysis, it is used to capture the potential effect of the particular characteristics of new pension plan launches; particularly, small size and low fees, but also greater inflow sensitivity to good performance (see Chevalier and Ellison, 1997).

Panel data analysis with random effects is used to account for unobservable firm-specific effects. All estimations use a family cluster to capture correlations between different plans affected in the same time period in each family and $\varepsilon_{i t}$ is the error term.

\section{6.- Results}

\section{1.- Fees and plan type}

The estimates for Model 1 (see Table 2), both with and without the lagged dependent variable, clearly show that the total fees in employer-sponsored plans are significantly lower, which provides clear support for the rejection of the null hypothesis H01, in favour 
of our alternative hypothesis HA1, and highlights the relevance of plan governance structures, in this case, through the higher degree of bargaining power held by the investor/decision-maker. In fact, fees in employer-sponsored plans, unconditional on other variables, are just over $27 \%$ of those found in individual plans, with the difference significant at $1 \%$. This difference is both statistically and economically significant. The results for the variable, Emp, are in line with those reported in the literature for institutional versus retail investors. In this case, however, the differences are not between the participants in individual/employer-sponsored plans, but in the respective plan governance structure, which, in the latter case, includes, in representation of the whole collective, a decision-maker with objectives in perfect alignment with those of the participants, a high degree of monitoring capacity and bargaining power based on the possible threat of dismissal of the management (and custody) firm. The results of the marginal effects, also shown in Table 2, fully confirm the negative differential effect found for employer-sponsored plans.

\section{2.- Performance and plan type}

The estimates for Model 2, given in Table 3, clearly show employer-sponsored plans to have the better performance indicators, whether performance is calculated before and after fees. The difference is therefore not entirely due to the above-reported result for fees. This effect on performance appears to be linked to the greater monitoring capacity and the permanent option to dismiss the management firm which exist in employer-sponsored plans. In the gross performance measure, the only significant variables apart from the dummy for employer-sponsored plans are baseline performance and size of management firm, which suggests possible scale economies. Apart from these variables, net performance is negatively influenced by the total fees charged by the management and custody firms. In short, the null hypothesis, H02, is rejected in favour of the alternative, HA2, which states that employer-sponsored plans perform better than individual ones, both before and after fees. In fact, the results of the performance measures, unconditional on other variables, reveal that gross performance is 2.59 times higher, and net performance 3.80 times higher in employer-sponsored than in individual plans, with differences significant at $1 \%$ in both cases. 


\section{3.- Effects deriving from the simultaneous management of individual and employer- sponsored plans by the same firm}

To test for a positive effect (possible synergies) or a negative effect (possible cross-plan subsidization) resulting from a single firm managing two different types of plan with different corporate governance structures, the fee and performance estimations will include two dummy variables: IBoth and EBoth. IBoth (EBoth) is a dummy variable which is equal to 1 if the plan is individual (employer-sponsored) and is managed by a management firm that also manages employer-sponsored (individual) plans and 0 otherwise. It is worth noting that the size differences between management firms specializing in one type of plan and those handling both types are controlled by the aforementioned variable, SizeMgFirm.

Table 4 presents the results of the Tobit estimation (Model 1) including the variables IBoth and EBoth in addition to the set of independent variables used in the previous estimation. It can be seen that, whether the variable Feeslag is included or not, fees are significantly higher for individual plans managed by firms handling both types of plan (IBoth) than for those managed by firms handling individual plans only. This suggests that firms are emboldened by the weak corporate governance structure of individual plans to charge them higher fees, either simply to increase their own income, or to subsidize employersponsored plans and thus make these more attractive to prospective investors. To test this last possibility, we need to analyse the results for the variable EBoth. The possibility appears to be confirmed by the first estimation, in which EBoth shows a negative sign and is significant. The significance is lost with the inclusion of lagged fees, however, leaving the results less conclusive. The results overall fail to provide any clear evidence to confirm that firms charge individual plans higher fees in order to reduce those charged to employer-sponsored plans, despite some indications that this may in fact occur. In any case, the strategy devised by firms handling both types of plan appears to be to maximize income by exploiting the weakest link in the chain (individual plans), although we find no evidence of their sharing the resulting profit with employer-sponsored plans. Subsidization may also occur in hidden costs, but this would be visible only in terms of performance, not in explicit costs, such as fees. 
The results of the performance analysis based on panel data estimation (Model 2) with the addition of the new variables IBoth and EBoth are fairly enlightening (see Table 5). Their interpretation requires making a distinction between before-fees and after-fees performance. It is clear that before-fees performance is better in employer-sponsored than in individual plans and better still in employer-sponsored plans managed by firms that also handle individual plans. Poorer performance is observed in individual plans managed by firms that handle both types, although the p-value is slightly beyond conventional significance levels (0.13). The findings are much clearer for after-fees performance, which is significantly worse in individual plans managed by firms that also handle employer-sponsored plans. These results are consistent with the subsidization hypothesis. Regrettably, the information available from the DGS is far from sufficient to enable us to undertake the analyses that would be required to confirm the channel used for subsidization. In any case, the evidence of Gaspar et al. (2006), shows that subsidization occurs between funds within the same family, but not necessarily managed by the same firm. This increases the plausibility of subsidization between pension plans managed by the same firm, when investors in one type (individual plans) have a low level of monitoring capacity and limited bargaining power.

In short, the results lead to the rejection of hypothesis H03 in favour of the alternative HA3.2, which posits that there is a negative effect on individual plans managed by firms that handle both types of pension plan. This effect may be the result of cross-plan subsidization having detrimental consequences for investors in individual plans.

\section{4.- Robustness checks}

\subsubsection{The time points for the control variables}

In the above estimations, both of fees and performance, the control variables were lagged by one period (t-1) in order to control for potential endogeneity among the plan-level explanatory variables. However, especially in the case of fees, year-end values were used, although annual averages $\left(t^{*}\right)$ or even contemporary measures $(t)$ could have been included. To determine whether the results are conditioned by the chosen option, the 
Tobit models were re-estimated including the annual averages of the variables Perf, Var and SizeMgFirm. Table 6 illustrates the impact of plan type on fees, and again confirms that fees are significantly lower in employer-sponsored than in individual plans, while the rest of the results remain unaltered. Meanwhile, Table 7 shows the results of management of employer-sponsored and individual plans by the same management firm. In line with the results obtained previously, individual plans managed by firms that also handle employer-sponsored plans report significantly higher fees than those managed by firms that handle only individual plans. The results for employer-sponsored plans managed by firms also handling individual plans appear to support the subsidization hypothesis, given the negative sign and significance of the variable EBoth. The significance fades when the lagged dependent variable is added.

\subsubsection{Performance and risk}

For the performance analysis, the model considers both the annual averages of the variables and also the variable Var. Note that, although when estimating fees it is quite reasonable to consider some plan-risk measure, given the possible association between risk and fees, the need for this is less obvious when analysing a performance measure that is already risk-adjusted. However, for the sake of consistency in the analysis of the two variables (fees and performance), risk was included in this robustness check.

Table 8 presents the results for plan performance differences (individual versus employersponsored). Panel A gives the results with the addition of the variable Var to the initial estimation presented in Table 3 (with the control variables lagged by one year) and Panel $B$ with the addition of the variable Var and the annual averages of the control variables. In line with those obtained previously, the results in both cases reveal that employersponsored plans perform significantly better both before and after fees. Fees have a negative effect on performance and size of management firm has a positive effect on performance in all cases. Thus, neither the measurement of the control variables at $\mathrm{t}-1$ or $t^{*}$, nor the inclusion of risk (which is positive and significant only for Net Performance) in any way alters the findings already obtained. 
Finally, Table 9 presents the results from the above considerations (including or omitting the lag of the control variables and risk) in the analysis of the case where individual and employer-sponsored plans are managed by the same firm. Again, the results for the different variables continue to hold both including risk (Panel A) and including, in addition, annual averages of the control variables (Panel B), indicating that individual plans are subject to potential parasitic exploitation from employer-sponsored plans, as detected in the initial analysis (Table 5) and providing further evidence of their robustness to these additional considerations.

\subsubsection{CLAD estimation}

As well as specific issues ensuing from the unsuitability of Tobit regressions for the estimation of fractional variables, Ramalho et al. (2011), also stress the stringent assumptions regarding the dependent variable, prior to censoring. In order to overcome this problem, we use the CLAD procedure, proposed by Powell (1984), which provides robust estimators. Stata allows only a lower limit or upper limit. Given the lack of null observations for Fees, we are able to use a CLAD model which is right censored at the fee cap and written as follows (Model 3):

$$
\begin{array}{ll}
y_{i}=\alpha+\beta^{\prime} x_{i}+u_{i} & \text { if } \underline{y} \leq \alpha+\beta^{\prime} x_{i}+u_{i} \leq \bar{y} \\
y_{i}=\bar{y} & \text { if } \alpha+\beta^{\prime} x_{i}+u_{i}>\bar{y}
\end{array}
$$

where $y_{i}$ is the Fee, is the maximum legal fee, $\beta$ is a $k x 1$ vector of unknown parameters, and $x_{i}$ is a vector of the same size containing all the explanatory variables of the total (management and custody) fee decision. The dependent variables are the same as those in Model 1.

Table 10 gives the CLAD estimates for the impact of corporate governance differences on fees. As in the Tobit estimation, the coefficient on Emp is negative and significant, using bootstrap estimations to correct the bias. The coefficients on the remaining variables, while not relevant to the analysis for our research objective, are also in line with those obtained by Tobit estimation. 
The last columns in the table give the IBoth and EBoth estimates from the analysis testing for possible parasitic exploitation as suggested by previous results. As in the previous estimation, the conclusions continue to hold. Emp is clearly negative and significant. IBoth is positive and significant and EBoth is negative and significant, indicating that in management firms simultaneously handling both employer-sponsored and individual plans, the fees for the latter are higher than in those handling individual plans only and the fees for employer-sponsored plans are lower than when employer-sponsored plans only are being managed. Although direct testing is not possible with the data currently available, this result is clearly consistent with the parasitic exploitation of individual plans by employer-sponsored plans, whose corporate governance structure provides supervisory and disciplinary mechanisms that facilitate the alignment of investors' interests and enable the dismissal of the management firm in the event of dissatisfaction with its management performance and fees.

\subsubsection{Other control variables included in the Fees estimation}

Abinzano et al. (2016) who analyse pension plan market penetration strategies, include in their Fees analysis two potentially key variables: plan size (SPlan) and average investment per participant (AvgInv). Splan is the log of plan assets in Euros, and AvgInv is the log of average investment size per plan participant. Note that the cited study obtains separate estimates for each plan type. It is particularly important to make this point clear in the case of the variable $A v g I n v$, because, in individual plans, this variable is a potential proxy for investor type and, thereby, for a difference in strategy on the part of the management firm. In employer-sponsored plans, on the other hand, due to the presence of a Control Committee with key decision-making capacity, what matters is the plan as whole, and not so much the amount each participant invests in it. There could be a marked difference in the role played by this variable in each type of plan, potentially inhibiting the interpretation of its sign and magnitude. Whatever the case, the aim of this robustness check is to incorporate these variables as additional control variables in order to see whether their inclusion alters our previous conclusions. Let us note at this point that, given the potential relationship between size of management firm and plan size, the former will be omitted so as to avoid including two size proxies. 
Table 11 gives the Fees estimates with the inclusion of the said control variables. As in the CLAD estimation, the conclusions remain the same. The variable Emp is negative and significant in both estimations, while IBoth is positive and significant and EBoth is negative and significant ${ }^{20}$.

\section{7.-Conclusions}

This paper analyses the role of pension plan governance structure by examining the impact on fees and performance in individual vs. employer-sponsored pension plans in the Spanish setting, where investors suffer (or benefit) from the consequences of their sharply contrasting governance structures.

Firstly, investors in individual plans who are dissatisfied with the actions of the management firm have practically no other option than to exercise their right of exit. In an environment where highly fragmented demand from individual investors contrasts with highly concentrated supply from management firms, right of exit contributes little to aligning managers' objectives with those of investors. In employer-sponsored plans, on the other hand, the decision-maker is the Control Committee, where half the voting rights are held by the plan promoter and the other half by the participants and beneficiaries. The responsibilities of this committee include monitoring and, if necessary, replacing the management firm and custody firm. Although the concentration of supply in the market for employer-sponsored pension plans is the same, if not slightly higher, than it is in the individual pension plan market, the concentration of demand is clearly higher. It is not the workers themselves but their employer who promotes the plans and the Control Committee who deals with the monitoring and decision-making. Taking into account that the Control Committee also has the power to maintain or replace the management firm, it obviously has a high degree of monitoring capacity and bargaining power, much higher, of course, than is possible for individual pension plan investors.

\footnotetext{
20 The performance estimation was repeated with these control variables included, despite this no longer being so directly justifiable. The resulting conclusions are practically identical, with none of the said control variables showing any statistical significance.
} 
Consistent with the above-mentioned differences, total (management and custody) fees for employer-sponsored plans are found to be significantly lower than for individual plans, and performance is significantly better, both before and after fees (2.6 and 3.8 times higher, respectively). These results confirm that the differences in plan governance structures are clearly effective in aligning the interests of the management firm with those of plan participants, which suggests that it might be worth adapting all plan governance structures to these parameters.

The paper has also shown that the absence of a Control Committee, which implies a low degree of monitoring capacity in conjunction with limited power to bargain with the management firm, places participants in individual plans in a position of vulnerability and at a clear disadvantage with respect to investors in employer-sponsored plans, who benefit from notably higher levels of bargaining power and monitoring capacity. Firms managing both types of plan exploit this situation in a manner consistent with the application of a parasitic strategy, whereby their fees for individual plans are higher than those of firms managing individual plans only and their fees for employer-sponsored plans are lower than those of firms managing employer-sponsored plans only. These results are transferable to the area of performance, especially when measured after fees. For example, individual plans managed by a firm that handles both types of plan show poorer performance than those managed by firms handling individual plans only. Conversely, employer-sponsored plans managed by a firm that handles both types of plan show better performance than those managed by firms handling employer-sponsored plans only. This is consistent with strategic action by management firms (or possibly fund families), in line with the evidence of cross-subsidization activities in mutual fund families presented by Gaspar et al. (2006). In this case, however, the phenomenon is not due to investors being in a better position to obtain higher returns or having the characteristics required to negotiate a better a fee. It is simple exploitation of the fact that some plans (individual ones) have limited monitoring capacity and a low level of bargaining power with which to achieve their objectives, while others (employer-sponsored plans) have high degrees of monitoring capacity and bargaining power, including the option to threaten the management or custody firm with dismissal. This last factor is of indubitable relevance, since it could 
seriously reduce such firms' total assets under management, and thereby undermine their main source of income.

The findings on fees may be also extended to other expenses. Indeed, the confirmation of the differences observed in explicit costs, which are publicly available and easily verifiable, suggests that similar activity might be affecting hidden costs, the very nature of which makes them impervious to external monitoring and control. The observed performance differences, therefore, may not be entirely due to stronger motivation and interest in achieving performance gains through higher monitoring capacity. They could also be due to the different nature of this type of costs, which are less closely monitored. Unfortunately, despite the potential interest of this issue, further exploration is not possible with the data currently available.

The results also support the adoption of legal measures to guarantee majority board representation for investors, rather than an exclusive focus on controlling the percentage of independent directors. Combinations with other mechanisms, such as managerial ownership (Khorana et al. 2007) or the ownership stakes of the directors (Cremers et al. 2008), which have proved to be efficient mechanisms for aligning the objectives of the different parties, could also be considered.

Finally, it appears that Spain's economic authorities need to introduce legislative measures to endow individual plans with an internal corporate governance structure similar to that of employer-sponsored plans, whose participants, according to the evidence from this study, pay noticeably lower fees and obtain higher returns. The results indicate that this could satisfactorily address the existing lack of protection for the rights of individual plan participants whose only current recourse is to complain to the investor advocate (Defensor del Partícipe) or to exercise their right of exit, and whose disciplinary capacity vis-à-vis the management firm is circumscribed by a highly concentrated supply market.

\section{References}

Abinzano, I., Muga, L. and Santamaria, R. (2016). "The Role of Investor Type in the Fee Structures of Pension Plans". Journal of Financial Services Research, 50, 3, 387-417. 
Antolin, P. (2008). "Pension Fund Performance". OECD Working Papers on Insurance and Private Pensions, 20, OECD publishing, doi:10.1787/240401404057

Casterella, J. R., Francis, J. R., Lewis, B. L., and Walker, P. L. (2004). “Auditor industry specialization, client bargaining power and audit pricing". Auditing: A Journal of Practice and Theory, 23, 1, 123-140.

Chen C.R and Huang Y. (2011). "Mutual Fund Governance and Performance: A Quantile Regression Analysis of Morningstar's Stewardship Grade". Corporate Governance: An International Review, 19(4), 311-333

Chen, J., Hong, H., Huang, M., and Kubik, J. D. (2004). “Does Fund Size Erode Mutual Fund Performance? The Role of Liquidity and Organization". American Economic Review, $94,5,1276-1302$.

Chevalier, J., Ellison, G., (1997). "Risk taking by mutual funds as a response to incentives". Journal of Political Economy, 105, 1167-1200.

Christoffersen, S.E.K. (2001). "Why Do Money Fund Managers Voluntarily Waive Their Fees?". Journal of Finance, 61, 3, 1117-1140.

Christoffersen, S. and Musto, D. (2002). “Demand curves and the pricing of money management". Review of Financial Studies, 15, 1499 - 1524.

Cremers, M., Driessen, J., Maenhout, P. and Weinbaum, D. (2009). “Does Skin in the Game Matter? Director Incentives and Governance in the Mutual Fund Industry". Journal of Financial and Quantitative Analysis, 44, 6, 1345-1373

Cumming, D., Johan, S., Zhang, Y. (2016). “A Dissection of Mutual Fund Fees, Flows, and Performance". Available at SSRN: http://ssrn.com/abstract $=2678260$ or http:/ / dx.doi.org/10.2139/ssrn.2678260.

Del Guercio, D., and Tkac, P.A. (2002). "The Determinants of the Flow of Funds of Managed Portfolios: Mutual Funds vs. Pension Funds". Journal of Financial and Quantitative Analysis, 37, 4, 523-557. 
Ding, B. and Wermers, R. (2012). “Mutual Fund Performance and Governance Structure: The Role of Portfolio Managers and Boards of Directors" Available at SSRN: http:/ / ssrn.com/abstract=2207229 or http:// dx.doi.org/10.2139/ssrn.2207229.

Evans R.B. and Fahlenbrach, R. (2012). "Institutional investors and mutual fund governance. Evidence from retail-institutional fund twins". Review of Financial Studies, 25, $12,3530-3571$.

Fama, E. F., and Jensen, M. C. (1983). “Agency problems and residual claims". Journal of Law and Economics, 26, 275-302.

Ferris, S.P. and Yan, X.S. (2007). "Agency conflicts in delegated portfolio management: Evidence from Namesake mutual funds". Journal of Financial Research, 30, 4, 473-494.

Gaspar, J.M, Massa, M. and Matos, P. (2006). “Favoritism in Mutual Fund Families? Evidence on Strategic Cross-Fund Subsidization". Journal of Finance, 61(1), 73-104.

Goyal, A. and Wahal, S. (2008). "The Selection and Termination of Investment Management Firms by Plan Sponsors". Journal of Finance, 63, 4, 1805-1847.

Haslem, J.A. (2012). "Mutual fund total cost construct". Journal of Index Investing, 3, 3, 2733.

Hoffman, W.M., Neill, J.D. and Stovall, O.S. (2008). “Mutual Fund Compliance Officer Independence and Corporate Governance". Corporate Governance: An International Review, $16,1,52-60$.

Hutcheson, M.D., (2007). “Uncovering and Understanding Hidden Fees in Qualified Retirement Plans". Elder Law Journal, 15, 2. Available at SSRN: http:/ / ssrn.com/ abstract=961996 or http:/ / dx.doi.org/10.2139/ssrn.961996.

Ingley, C.B. and Van der Walt, N.T. (2004). “Corporate governance, institutional investors and conflicts of interest". Corporate Governance: An International Review, 12, 4, 534-551.

Ivković, Z. and Weisbenner, S. (2009). "Individual Investor Mutual Fund Flows". Journal of Financial Economics, 92 (2), 223-237. 
James, C. and Karceski, J. (2006). "Investor monitoring and differences in mutual fund performance". Journal of Banking and Finance, 30, 2787-2808.

Khorana, A. (1996). “Top management turnover. An empirical investigation of mutual fund managers". Journal of Financial Economics, 40, 403-427.

Khorana, A., Servaes, H. and Wedge, L. (2007). "Portfolio managers ownership and fund performance". Journal of Financial Economics, 85, 179-204,

Khorana, A., Servaes, H., Tufano, P. (2008). "Mutual fund fees around the World". Review of Financial Studies, 22, 3, 1279 - 1310.

Kwak, T., Kim, J., and Moon, C. (2006). “Supplier-buyer models for the bargaining process over a long-term replenishment contract". Computer and Industrial Engineering, 51, 219-228.

Luo, G. (2002). "Mutual Fund Fee-Setting, Market Structure and Mark-Ups". Economica, 69, 274, 245-71.

Mahoney, P.G. (2004). "Manager-investor conflicts in mutual funds". Journal of Economic Perspectives, 18, 2, 161-182.

Muga, L., Santamaría, R. (2010). “Market penetration strategies and the Fee-performance relationship: The case of the Spanish Money Mutual Funds". Service Industries Journal, 30, 1529-1547.

Palmiter, A.R. (2006). “The Mutual Fund Board: A Failed Experiment in Regulatory Outsourcing". Brooklyn. Journal of Corporate Financial \& Commercial Law, 1, 1. Available at: http:// brooklynworks.brooklaw.edu/bjcfcl/vol1/iss1/7

Powell, J.L. (1984). "Least absolute deviations estimation for the censored regression model". Journal of Econometrics, 25, 1, 303-325.

Ramalho, E., Ramalho, J., and Murteira, J. (2011). "Alternative estimating and testing empirical strategies for fractional regression models". Journal of Economic Surveys, 25, 1, 19 68.

Roth, S. (2006). "Negotiating prices for customized service". Journal of Service Research, 8, 4, 316-329. 
Stewart, F., and Yermo, J. (2009). "Pension fund governance: Challenges and potential solutions". OECD Journal: Financial Market Trends, 2008, 2., http://dx.doi.org/10.1787/fmtv2008-art17-en.

Tan M.G-S., and Cam, M-A. (2015). "Does governance structure influence pension fund fees and costs? An examination of Australian not-for-profit superannuation funds". Australian Journal of Management, 40, 1, 114-134.

Tufano, P., and Sevick, M. (1997). “Board structure and fee-setting in the U.S. mutual fund industry". Journal of Financial Economics, 46, 321-356

Wu, S. Y. and Wu, A. (2007). "Information Asymmetry, Bargaining Power and Customer Profitability: An Empirical Investigation on Bank-Client Relationship". AAA 2008 MAS Meeting Paper. Available at SSRN: http://ssrn.com/abstract $=1004079$ or http:// dx.doi.org/10.2139/ssrn.1004079. 
Table 1: Sample. Descriptive Statistics

Panel A: Descriptive Statistics

\begin{tabular}{lrrrrrr}
\hline & Avg & SD & $10 \%$ & $90 \%$ & Avg Emp & Avg Ind \\
\hline Fees & 1.226 & 0.820 & 0.200 & 2.300 & 0.469 & 1.807 \\
Sharpe Ratio before & & & & & & \\
fees & 0.532 & 1.062 & -1.226 & 1.805 & 0.790 & 0.334 \\
Sharpe Ratio after fees & 0.426 & 1.045 & -1.306 & 1.692 & 0.704 & 0.212 \\
Var & 13.072 & 8.758 & 3.670 & 26.665 & 6.339 & 18.244 \\
SizeMgFirm & 20.945 & 1.349 & 19.278 & 22.520 & 21.190 & 20.756 \\
\hline N. Funds & & & & & 34 & 143 \\
N. Plans & & & & & 151 & 226 \\
\hline
\end{tabular}

\% Plans/year managed by a firm handling both types (Employer sponsored and Individual)

Panel B: Correlation Matrix

\begin{tabular}{|c|c|c|c|c|c|c|c|c|c|c|}
\hline & Perf & Emp & Fees & SizMgFirm & Splan & AvgInv & New & Var & IBoth & EBoth \\
\hline Perf & 1 & & & & & & & & & \\
\hline Emp & 0.21 & 1 & & & & & & & & \\
\hline Fees & -0.19 & -0.81 & 1 & & & & & & & \\
\hline SizMgFirm & 0.13 & 0.17 & -0.14 & 1 & & & & & & \\
\hline Splan & 0.05 & -0.32 & 0.34 & 0.14 & 1 & & & & & \\
\hline AvgInv & 0.20 & -0.03 & -0.08 & 0.05 & 0.24 & 1 & & & & \\
\hline New & 0.01 & -0.07 & 0.02 & 0.00 & -0.09 & -0.09 & 1 & & & \\
\hline Var & -0.37 & -0.68 & 0.62 & -0.09 & 0.36 & -0.04 & -0.05 & 1 & & \\
\hline IBoth & -0.01 & -0.18 & 0.14 & 0.03 & 0.10 & -0.02 & -0.01 & 0.06 & 1 & \\
\hline EBoth & 0.21 & 0.99 & -0.81 & 0.20 & -0.31 & -0.02 & -0.07 & -0.67 & -0.18 & 1 \\
\hline
\end{tabular}

Table 1: Panel A gives descriptive statistics for the sample and Panel B the correlation matrix. Fees are total fees (management plus custody fees) expressed in \%. The Sharpe Ratio, before and after fees, measures contemporaneous risk-adjusted pension plan performance. Perf (before fees) is proxied by the Sharpe Ratio. Emp which is equal to 1 in the case of employer-sponsored plans and 0 otherwise. SizeMgFirm is Size of Management Firm computed as the log of its total assets under management., Splan is the log of plan assets in Euros, AvgInv is the log of average investment size per plan participant, a dummy variable New representing the first year of a pension plan, Var is the measure of the risk of the plan computed as plan return variance, IBoth which is equal to 1 in the case of individual plans managed by a firm that also manages employer-sponsored plans and 0 otherwise and EBoth which is equal to 1 in the case of employer-sponsored plans managed by a firm that also manages individual plans and 0 otherwise. 
Table 2: Type of Pension Plans and Fees.

\begin{tabular}{|c|c|c|c|c|c|c|}
\hline \multicolumn{7}{|c|}{ Panel A: Tobit Estimation } \\
\hline & Coef & $\mathrm{SE}$ & $\mathrm{p}$-value & Coef & SE & $\mathrm{p}$-value \\
\hline C & 1.755 & 0.233 & 0.00 & 0.042 & 0.090 & 0.64 \\
\hline Emp & -1.046 & 0.087 & 0.00 & -0.127 & 0.037 & 0.00 \\
\hline Perf & 0.016 & 0.025 & 0.52 & -0.018 & 0.016 & 0.26 \\
\hline Var & 0.011 & 0.003 & 0.00 & 0.001 & 0.002 & 0.53 \\
\hline New & -0.087 & 0.093 & 0.35 & 0.094 & 0.065 & 0.15 \\
\hline SizeMgFirm & -0.004 & 0.012 & 0.75 & 0.008 & 0.005 & 0.10 \\
\hline Feeslag & & & & 0.883 & 0.017 & 0.00 \\
\hline Year Effects & \multicolumn{3}{|c|}{ Yes } & \multicolumn{2}{|c|}{ Yes } & \\
\hline Family Effects & \multicolumn{2}{|c|}{ Yes } & & \multicolumn{2}{|c|}{ Yes } & \\
\hline K and $\mathrm{N}$ & 16 & 2309 & & 17 & 2308 & \\
\hline $\mathrm{F}(\mathrm{K}, \mathrm{N})$ & 398.66 & & 0.00 & 3768.32 & & 0.00 \\
\hline \multicolumn{7}{|c|}{ Panel B: Marginal Effects I. Tobit Estimation. E(Fees/0<y<2.5) } \\
\hline Emp & -0.914 & 0.069 & 0.00 & -0.127 & 0.037 & 0.00 \\
\hline Perf & 0.015 & 0.024 & 0.52 & -0.018 & 0.016 & 0.26 \\
\hline Var & 0.011 & 0.002 & 0.00 & 0.001 & 0.002 & 0.53 \\
\hline New & -0.081 & 0.086 & 0.35 & 0.094 & 0.065 & 0.15 \\
\hline SizeMgFirm & -0.003 & 0.011 & 0.75 & 0.008 & 0.005 & 0.10 \\
\hline Feeslag & & & & 0.883 & 0.017 & 0.00 \\
\hline \multicolumn{7}{|c|}{ Panel C: Marginal Effects II. Tobit Estimation. E(Fees $/ 0<\mathrm{y}<2.5)$} \\
\hline Emp & -1.017 & 0.081 & 0.00 & -0.127 & 0.037 & 0.00 \\
\hline Perf & 0.016 & 0.025 & 0.52 & -0.018 & 0.016 & 0.26 \\
\hline Var & 0.011 & 0.003 & 0.00 & 0.001 & 0.002 & 0.53 \\
\hline New & -0.086 & 0.092 & 0.35 & 0.094 & 0.065 & 0.15 \\
\hline SizeMgFirm & -0.004 & 0.011 & 0.75 & 0.008 & 0.005 & 0.10 \\
\hline Feeslag & & & & 0.883 & 0.017 & 0.00 \\
\hline
\end{tabular}

Results of the estimation of the Tobit model for employer-sponsored and individual plans. Coef is the coefficient estimate, and SE is the robust standard error. The dependent variable is total plan fees (management+custody) expressed in \% (Fees). The independent variables are a dummy variable Emp which is equal to 1 in the case of employer-sponsored plans and 0 otherwise, Plan Performance (Perf), proxied by the Sharpe Ratio, variance of plan returns (Var), a dummy variable New representing the first year of a pension plan, Size of Management firm (SizeMgFirm), proxied by its total assets under management, and the lag of total fees (Feeslag). Perf, Var and SizeMgFirm are lagged by one period. Fixed year effects and dummy variables representing the top families (average number of plans per year $>20$ ) are also included in the estimation. The table also shows the number of observations $(\mathrm{N})$ and the F-test for the model tested $(\mathrm{F}(\mathrm{K}, \mathrm{N})$. Panel B: Marginal Effects I: Tobit Estimation. E(Fees/0<Fees<2.5); where Fees is the censored dependent variable. Panel C: Marginal Effects II. Tobit Estimation. $\mathrm{E}\left(\mathrm{Fees}^{*} / 0<\mathrm{Fees}<2.0\right)$; where Fees* is the latent dependent variable. 
Table 3: Type of Pension Plans and Performance.

\begin{tabular}{|c|c|c|c|c|c|c|c|c|c|c|c|c|}
\hline & \multicolumn{3}{|c|}{ Performance } & \multicolumn{3}{|c|}{ Net Performance } & \multicolumn{3}{|c|}{ Performance } & \multicolumn{3}{|c|}{ Net Performance } \\
\hline & Coef & SE & p-val & Coef & SE & p-val & Coef & SE & p-val & Coef & SE & $\mathrm{p}$-va \\
\hline C & -1.810 & 0.213 & 0.00 & -1.940 & 0.274 & 0.00 & -1.804 & 0.219 & 0.00 & -1.917 & 0.286 & 0.00 \\
\hline Emp & 0.183 & 0.070 & 0.01 & 0.200 & 0.082 & 0.02 & 0.181 & 0.070 & 0.01 & 0.195 & 0.081 & 0.02 \\
\hline Fees & 0.006 & 0.019 & 0.74 & -0.049 & 0.024 & 0.04 & 0.005 & 0.019 & 0.78 & -0.053 & 0.023 & 0.02 \\
\hline SizeMgFirm & 0.024 & 0.011 & 0.02 & 0.030 & 0.014 & 0.03 & 0.024 & 0.011 & 0.03 & 0.030 & 0.014 & 0.04 \\
\hline New & & & & & & & -0.030 & 0.110 & 0.78 & -0.103 & 0.120 & 0.39 \\
\hline Perf Initial & 0.353 & 0.094 & 0.00 & 0.277 & 0.122 & 0.02 & 0.353 & 0.095 & 0.00 & 0.278 & 0.123 & 0.02 \\
\hline Year Effects & & Yes & & & Yes & & & Yes & & & Yes & \\
\hline Family Effects & & Yes & & & Yes & & & Yes & & & Yes & \\
\hline $\mathrm{R} 2$ & 0.878 & & & 0.854 & & & 0.878 & & & 0.854 & & \\
\hline Wald & 39906 & & 0.00 & 35710 & & 0.00 & 40094 & & 0.00 & 36417 & & 0.00 \\
\hline \#Plans & 377 & & & 377 & & & 377 & & & 377 & & \\
\hline \#Observations & 2315 & & & 2315 & & & 2315 & & & 2315 & & \\
\hline
\end{tabular}

Results of the Panel Data estimation for employer-sponsored and individual plans. Coef is the coefficient estimate, and SE is the robust standard error. The dependent variable is plan Performance (before fees) and Net Performance (after fees) proxied by the Sharpe Ratio. The independent variables are a dummy variable, Emp, which is equal to 1 in the case of employer sponsored plans and 0 otherwise, total fees (management+custody fees) of the plan (Fees), Size of management firm (SizeMgFirm), proxied by its total assets under management, a dummy variable New representing the first year of a pension plan, and the plan's baseline performance (Perflnitial, year 2007). Fees and SizeMgFirm are lagged by one period. Fixed year effects and dummy variables representing the top families (average number of plans per year $>20$ ) are also included in the estimation. The table also shows the number of observations, number of Plans, the R2 and the Wald test. 
Table 4: Parasitic fee pattern.

\begin{tabular}{|c|c|c|c|c|c|c|}
\hline \multicolumn{7}{|c|}{ Panel A: Tobit Estimation } \\
\hline & Coef & SE & $\mathrm{p}$-value & Coef & SE & p-value \\
\hline C & 1.645 & 0.260 & 0.00 & 0.133 & 0.103 & 0.20 \\
\hline Emp & -0.666 & 0.104 & 0.00 & -0.088 & 0.049 & 0.08 \\
\hline IBoth & 0.216 & 0.067 & 0.00 & 0.056 & 0.025 & 0.03 \\
\hline EBoth & -0.256 & 0.140 & 0.07 & -0.007 & 0.050 & 0.89 \\
\hline Perf & 0.017 & 0.025 & 0.49 & -0.018 & 0.016 & 0.26 \\
\hline Var & 0.012 & 0.003 & 0.00 & 0.001 & 0.002 & 0.48 \\
\hline New & -0.082 & 0.093 & 0.38 & 0.094 & 0.065 & 0.15 \\
\hline SizeMgFirm & 0.001 & 0.013 & 0.97 & 0.003 & 0.005 & 0.57 \\
\hline Feeslag & & & & 0.881 & 0.018 & 0.00 \\
\hline Year Effects & & Yes & & & Yes & \\
\hline Family Effects & & Yes & & & Yes & \\
\hline $\mathrm{K}$ and $\mathrm{N}$ & 18 & 2309 & & 19 & 2308 & \\
\hline $\mathrm{F}(\mathrm{K}, \mathrm{N})$ & $364-24$ & & 0.00 & 3388.51 & & 0.00 \\
\hline \multicolumn{7}{|c|}{ Panel B: Marginal Effects I. Tobit Estimation. $\mathrm{E}($ Fees $/ 0<\mathrm{y}<2.5)$} \\
\hline Emp & -0.604 & 0.089 & 0.00 & -0.088 & 0.049 & 0.08 \\
\hline IBoth & 0.199 & 0.060 & 0.00 & 0.056 & 0.025 & 0.03 \\
\hline EBoth & -0.237 & 0.129 & 0.07 & -0.007 & 0.050 & 0.89 \\
\hline Perf & 0.016 & 0.023 & 0.49 & -0.018 & 0.016 & 0.26 \\
\hline Var & 0.011 & 0.002 & 0.00 & 0.001 & 0.002 & 0.48 \\
\hline New & -0.076 & 0.086 & 0.38 & 0.094 & 0.065 & 0.15 \\
\hline SizeMgFirm & 0.000 & 0.012 & 0.97 & 0.003 & 0.005 & 0.57 \\
\hline Feeslag & & & & 0.881 & 0.018 & 0.00 \\
\hline \multicolumn{7}{|c|}{ Panel C: Marginal Effects II. Tobit Estimation. E(Fees $* / 0<y<2.5)$} \\
\hline Emp & -0.655 & 0.101 & 0.00 & -0.088 & 0.049 & 0.08 \\
\hline IBoth & 0.213 & 0.066 & 0.00 & 0.056 & 0.025 & 0.03 \\
\hline EBoth & -0.253 & 0.138 & 0.07 & -0.007 & 0.050 & 0.89 \\
\hline Perf & 0.017 & 0.025 & 0.49 & -0.018 & 0.016 & 0.26 \\
\hline Var & 0.012 & 0.003 & 0.00 & 0.001 & 0.002 & 0.48 \\
\hline New & -0.081 & 0.092 & 0.38 & 0.094 & 0.065 & 0.15 \\
\hline SizeMgFirm & 0.001 & 0.013 & 0.97 & 0.003 & 0.005 & 0.57 \\
\hline Feeslag & & & & 0.881 & 0.018 & 0.00 \\
\hline
\end{tabular}

Results of the estimation of the Tobit model for employer-sponsored and individual plans. Coef is the coefficient estimate, and SE is the robust standard error. The dependent variable is total plan fees (management+custody) expressed in \% (Fees). The independent variables are a dummy variable Emp which is equal to 1 in the case of employer-sponsored plans and 0 otherwise, IBoth which is equal to 1 in the case of individual plans managed by a firm that also manages employersponsored plans and 0 otherwise, EBoth which is equal to 1 in the case of employer-sponsored plans managed by a firm that also manages individual plans and 0 otherwise, Plan Performance (Perf), proxied by the Sharpe Ratio, plan return variance (Var), a dummy variable New representing the first year of a pension plan, Size of Management firm (SizeMgFirm), proxied by its total assets under management, and the lag of total fees (Feeslag). Perf, Var and SizeMgFirm are lagged by one period. Fixed year effects and dummy variables representing the top families (average number of plans by year $>20$ ) are also included in the estimation. The table also shows the number of observations $(\mathrm{N})$ and the F-test for the model tested $(\mathrm{F}(\mathrm{K}, \mathrm{N})$. Panel B: Marginal Effects I: Tobit Estimation. E(Fees $/ 0<$ Fees $<2.5)$; where Fees is the censored dependent variable. Panel C: Marginal Effects II. Tobit Estimation. $\mathrm{E}\left(\right.$ Fees $^{*} / 0<$ Fees $\left.<2.0\right)$; where Fees ${ }^{*}$ is the latent dependent variable. 
Table 5 Parasitic performance pattern.

\begin{tabular}{|c|c|c|c|c|c|c|c|c|c|c|c|c|}
\hline & \multicolumn{3}{|c|}{ Performance } & \multicolumn{3}{|c|}{ Net Performance } & \multicolumn{3}{|c|}{ Performance } & \multicolumn{3}{|c|}{ Net Performance } \\
\hline & Coef & SE & p-val & Coef & SE & p-val & Coef & SE & p-val & Coef & SE & p-val \\
\hline C & -1.768 & 0.193 & 0.00 & -1.868 & 0.228 & 0.00 & -1.760 & 0.199 & 0.00 & -1.843 & 0.241 & 0.00 \\
\hline Emp & 0.157 & 0.091 & 0.09 & 0.179 & 0.099 & 0.07 & 0.156 & 0.091 & 0.09 & 0.177 & 0.098 & 0.07 \\
\hline IBoth & -0.103 & 0.067 & 0.13 & -0.120 & 0.068 & 0.08 & -0.101 & 0.067 & 0.13 & -0.116 & 0.068 & 0.09 \\
\hline EBoth & 0.315 & 0.144 & 0.03 & 0.509 & 0.162 & 0.00 & 0.317 & 0.143 & 0.03 & 0.516 & 0.162 & 0.00 \\
\hline Fees & 0.008 & 0.019 & 0.66 & -0.048 & 0.024 & 0.05 & 0.007 & 0.019 & 0.71 & -0.052 & 0.024 & 0.03 \\
\hline SizeMgFirm & 0.021 & 0.010 & 0.03 & 0.026 & 0.011 & 0.02 & 0.021 & 0.010 & 0.03 & 0.026 & 0.012 & 0.03 \\
\hline New & & & & & & & -0.032 & 0.109 & 0.77 & -0.106 & 0.119 & 0.38 \\
\hline Perf Initial & 0.350 & 0.094 & 0.00 & 0.275 & 0.122 & 0.02 & 0.351 & 0.094 & 0.00 & 0.275 & 0.123 & 0.03 \\
\hline Year Effects & & Yes & & & Yes & & & Yes & & & Yes & \\
\hline Family Effects & & Yes & & & Yes & & & Yes & & & Yes & \\
\hline $\begin{array}{l}\text { IBoth=EBoth } \\
\chi^{2}(1)\end{array}$ & 9.12 & & 0.00 & 16.47 & & 0.00 & 9.28 & & 0.00 & 16.64 & & 0.00 \\
\hline $\mathrm{R} 2$ & 0.8981 & & & 0.857 & & & 0.881 & & & 0.857 & & \\
\hline Wald & 43717 & & 0.00 & 28478 & & 0.00 & 43886 & & 0.00 & 39513 & & \\
\hline \#Plans & 377 & & & 377 & & & 377 & & & 377 & & \\
\hline \#Observations & 2308 & & & 2308 & & & 2308 & & & 2308 & & \\
\hline
\end{tabular}

Results of the Panel Data estimation for employer-sponsored and individual plans. Coef is the coefficient estimate, and SE is the robust standard error of the estimate. The dependent variable is Plan Performance (before fees) and Net Performance (after fees) proxied by the Sharpe Ratio. The independent variables are a dummy variable, Emp, which is equal to 1 in the case of employer-sponsored plans and 0 otherwise, IBoth which is equal to 1 in the case of individual plans managed by a firm that also manages employer-sponsored plans and 0 otherwise, EBoth which is equal to 1 in the case of employer-sponsored plans managed by a firm that also manages individual plans and 0 otherwise, total plan fees (management+custody fees) (Fees), Size of management firm (SizeMgFirm), proxied by its total assets under management (SizeMgFirm) a dummy variable, New, representing the first year of a pension plan, and the plan's baseline performance (PerfInitial, year 2007). Fees and SizeMgFirm are lagged by one period. Fixed year effects and dummy variables representing the top families (average number of plans by year $>20$ ) are also included in the estimation. The table also shows the number of observations and number of plans, the $\mathrm{R} 2$ and the Wald tests. 
Table 6: Robustness Checks I: Types of Pension Plan and Fees.

\begin{tabular}{|c|c|c|c|c|c|c|}
\hline \multicolumn{7}{|c|}{ Panel A: Tobit Estimation (the control variables are measured as annual averages) } \\
\hline & Coef & SE & p-value & Coef & SE & p-value \\
\hline C & 1.741 & 0.247 & 0.00 & 0.058 & 0.094 & 0.54 \\
\hline Emp & -1.039 & 0.087 & 0.00 & -0.129 & 0.036 & 0.00 \\
\hline Perf & 0.032 & 0.031 & 0.31 & -0.010 & 0.023 & 0.68 \\
\hline Var & 0.012 & 0.003 & 0.00 & 0.001 & 0.001 & 0.55 \\
\hline New & -0.083 & 0.092 & 0.37 & 0.089 & 0.064 & 0.17 \\
\hline SizeMgFirm & -0.003 & 0.012 & 0.83 & 0.008 & 0.005 & 0.11 \\
\hline Feeslag & & & & 0.882 & 0.017 & 0.00 \\
\hline Year Effects & \multicolumn{3}{|c|}{ Yes } & \multicolumn{2}{|c|}{ Yes } & \\
\hline Family Effects & \multicolumn{2}{|c|}{ Yes } & & \multicolumn{2}{|c|}{ Yes } & \\
\hline K and $\mathrm{N}$ & 16 & 2309 & & 17 & 2308 & \\
\hline $\mathrm{F}(\mathrm{K}, \mathrm{N})$ & 398.57 & & 0.00 & 3789.321 & & 0.00 \\
\hline \multicolumn{7}{|c|}{ Panel B: Marginal Effects I. Tobit Estimation. E(Fees/0<y<2.5) } \\
\hline Emp & -0.909 & 0.070 & 0.00 & -0.129 & 0.036 & 0.00 \\
\hline Perf & 0.029 & 0.029 & 0.31 & -0.010 & 0.023 & 0.68 \\
\hline Var & 0.011 & 0.002 & 0.00 & 0.001 & 0.001 & 0.55 \\
\hline New & -0.077 & 0.085 & 0.37 & 0.089 & 0.064 & 0.17 \\
\hline SizeMgFirm & -0.002 & 0.011 & 0.83 & 0.008 & 0.005 & 0.11 \\
\hline Feeslag & & & & 0.882 & 0.017 & 0.00 \\
\hline \multicolumn{7}{|c|}{ Panel C: Marginal Effects II. Tobit Estimation. E(Fees $/ 0<\mathrm{y}<2.5)$} \\
\hline Emp & -1.011 & 0.082 & 0.00 & -0.129 & 0.036 & 0.00 \\
\hline Perf & 0.031 & 0.031 & 0.31 & -0.010 & 0.023 & 0.68 \\
\hline Var & 0.012 & 0.003 & 0.00 & 0.001 & 0.001 & 0.55 \\
\hline New & -0.082 & 0.091 & 0.37 & 0.089 & 0.064 & 0.17 \\
\hline SizeMgFirm & -0.003 & 0.012 & 0.83 & 0.008 & 0.005 & 0.11 \\
\hline Feeslag & & & & 0.882 & 0.017 & 0.00 \\
\hline
\end{tabular}

Results of the estimation of the Tobit model for employer-sponsored and individual plans. Coef is the coefficient estimate, and SE is the robust standard error. The dependent variable is total plan fees (management+custody) expressed in basis points (Fees). The independent variables are a dummy variable, Emp, which is equal to 1 in the case of employer-sponsored plans and 0 otherwise, Plan Performance (Perf), proxied by the Sharpe Ratio, plan return variance (Var), a dummy variable, New, representing the first year of a pension plan, Size of Management firm (SizeMgFirm), proxied by its total assets under management, and the lag of total fees (Feeslag). Perf, Var and SizeMgFirm are measured as annual averages. Fixed year effects and dummy variables representing the top families (average number of plans per year>20) are also included in the estimation. The table also shows the number of observations $(\mathrm{N})$ and the F-test for the model tested $(\mathrm{F}(\mathrm{K}, \mathrm{N})$. Panel B: Marginal Effects I: Tobit Estimation. E(Fees $/ 0<$ Fees $<2.5)$; where Fees is the censored dependent variable. Panel C: Marginal Effects II. Tobit Estimation. E(Fees* $/ 0<$ Fees $<2.0)$; where Fees* is the latent dependent variable. 
Table 7: Robustness Checks II: Parasitic fee patterns.

\begin{tabular}{|c|c|c|c|c|c|c|}
\hline \multicolumn{7}{|c|}{ Panel A: Tobit Estimation (the control variables are measured as annual averages) } \\
\hline & Coef & SE & p-value & Coef & SE & $\mathrm{p}$-value \\
\hline C & 1.614 & 0.276 & 0.00 & 0.152 & 0.106 & 0.15 \\
\hline Emp & -0.626 & 0.108 & 0.00 & -0.088 & 0.051 & 0.09 \\
\hline IBoth & 0.212 & 0.068 & 0.00 & 0.054 & 0.025 & 0.03 \\
\hline EBoth & -0.294 & 0.145 & 0.04 & -0.010 & 0.051 & 0.84 \\
\hline Perf & 0.038 & 0.031 & 0.22 & -0.008 & 0.024 & 0.74 \\
\hline Var & 0.012 & 0.003 & 0.00 & 0.001 & 0.001 & 0.50 \\
\hline New & -0.079 & 0.092 & 0.39 & 0.089 & 0.064 & 0.17 \\
\hline SizeMgFirm & 0.003 & 0.013 & 0.83 & 0.003 & 0.005 & 0.59 \\
\hline Feeslag & & & & 0.881 & 0.017 & 0.00 \\
\hline Year Effects & & Yes & & & Yes & \\
\hline Family Effects & & Yes & & & Yes & \\
\hline $\mathrm{K}$ and $\mathrm{N}$ & 18 & 2309 & & 19 & 2308 & \\
\hline $\mathrm{F}(\mathrm{K}, \mathrm{N})$ & 364.50 & & 0.00 & 3408.47 & & 0.00 \\
\hline \multicolumn{7}{|c|}{ Panel B: Marginal Effects I. Tobit Estimation. E(Fees/0<y<2.5) } \\
\hline Emp & -0.570 & 0.094 & 0.00 & -0.088 & 0.051 & 0.09 \\
\hline IBoth & 0.196 & 0.061 & 0.00 & 0.054 & 0.025 & 0.03 \\
\hline EBoth & -0.272 & 0.134 & 0.04 & -0.010 & 0.051 & 0.84 \\
\hline Perf & 0.035 & 0.029 & 0.22 & -0.008 & 0.024 & 0.74 \\
\hline Var & 0.012 & 0.002 & 0.00 & 0.001 & 0.001 & 0.50 \\
\hline New & -0.073 & 0.085 & 0.39 & 0.089 & 0.064 & 0.17 \\
\hline SizeMgFirm & 0.003 & 0.013 & 0.83 & 0.003 & 0.005 & 0.59 \\
\hline Feeslag & & & & 0.881 & 0.017 & 0.00 \\
\hline \multicolumn{7}{|c|}{ Panel C: Marginal Effects II. Tobit Estimation. E(Fees $* 0<\mathrm{y}<2.5)$} \\
\hline Emp & -0.617 & 0.105 & 0.00 & -0.088 & 0.051 & 0.09 \\
\hline IBoth & 0.210 & 0.067 & 0.00 & 0.054 & 0.025 & 0.03 \\
\hline EBoth & -0.291 & 0.144 & 0.04 & -0.010 & 0.051 & 0.84 \\
\hline Perf & 0.037 & 0.031 & 0.22 & -0.008 & 0.024 & 0.74 \\
\hline Var & 0.012 & 0.003 & 0.00 & 0.001 & 0.001 & 0.50 \\
\hline New & -0.078 & 0.091 & 0.39 & 0.089 & 0.064 & 0.17 \\
\hline SizeMgFirm & 0.003 & 0.013 & 0.83 & 0.003 & 0.005 & 0.59 \\
\hline Feeslag & & & & 0.881 & 0.017 & 0.00 \\
\hline
\end{tabular}

Results of the estimation of the Tobit model for employer-sponsored and individual plans. Coef is the coefficient estimate, and SE is the robust standard error. The dependent variable is total plan fees (management+custody) expressed in \% (Fees). The independent variables are a dummy variable, Emp, which is equal to 1 in the case of employer-sponsored plans and 0 otherwise, IBoth which is equal to 1 in the case of individual plans managed by a firm that also manages employersponsored plans and 0 otherwise, EBoth, which is equal to 1 in the case of employer-sponsored plans managed by a firm that also manages individual plans and 0 otherwise, Plan Performance (Perf), proxied by the Sharpe Ratio, plan return variance (Var), a dummy variable, New, representing the first year of a pension plan, Size of Management firm (SizeMgFirm), proxied by its total assets under management, and the lag of total fees (Feeslag). Perf, Var and SizeMgFirm are measured as annual averages. Fixed year effects and dummy variables representing the top families (average number of plans per year $>20$ ) are also included in the estimation. The table also shows the number of observations $(\mathrm{N})$ and the F-test for the model tested $(\mathrm{F}(\mathrm{K}, \mathrm{N})$. Panel B: Marginal Effects I: Tobit Estimation. $\mathrm{E}($ Fees $/ 0<$ Fees $<2.5)$; where Fees is the censored dependent variable. Panel C: Marginal Effects II. Tobit Estimation. E $($ Fees* $/ 0<$ Fees $<2.0)$; where Fees ${ }^{*}$ is the latent dependent variable. 
Table 8: Robustness Checks III: Types of Pension Plan and Performance.

\begin{tabular}{|c|c|c|c|c|c|c|c|c|c|c|c|c|}
\hline & \multicolumn{3}{|c|}{ Performance } & \multicolumn{3}{|c|}{ Net Performance } & \multicolumn{3}{|c|}{ Performance } & \multicolumn{3}{|c|}{ Net Performance } \\
\hline & Coef & SE & p-val & Coef & SE & p-val & Coef & SE & p-val & Coef & SE & p-val \\
\hline \multicolumn{13}{|c|}{ Panel A (the control variables are lagged by one period) } \\
\hline C & -1.818 & 0.220 & 0.00 & -2.045 & 0.278 & 0.00 & -1.811 & 0.228 & 0.00 & -2.031 & 0.291 & 0.00 \\
\hline Emp & 0.186 & 0.075 & 0.01 & 0.259 & 0.090 & 0.00 & 0.183 & 0.075 & 0.02 & 0.254 & 0.090 & 0.01 \\
\hline Fees & 0.005 & 0.019 & 0.79 & -0.064 & 0.026 & 0.01 & 0.004 & 0.019 & 0.82 & -0.065 & 0.025 & 0.01 \\
\hline SizeMgFirm & 0.024 & 0.010 & 0.02 & 0.026 & 0.013 & 0.04 & 0.024 & 0.011 & 0.03 & 0.026 & 0.013 & 0.04 \\
\hline Var & 0.001 & 0.003 & 0.80 & 0.010 & 0.004 & 0.01 & 0.000 & 0.003 & 0.88 & 0.009 & 0.004 & 0.02 \\
\hline New & & & & & & & -0.028 & 0.114 & 0.81 & -0.047 & 0.125 & 0.71 \\
\hline Perf Initial & 0.353 & 0.094 & 0.00 & 0.278 & 0.119 & 0.02 & 0.353 & 0.094 & 0.00 & 0.279 & 0.120 & 0.02 \\
\hline Year Effects & & Yes & & & Yes & & & Yes & & & Yes & \\
\hline Family Effects & & Yes & & & Yes & & & Yes & & & Yes & \\
\hline R2 & 0.878 & & & 0.854 & & & 0.878 & & & 0.854 & & \\
\hline Wald & 40720 & & 0.00 & 4252 & & 0.00 & 40728 & & 0.00 & 40656 & & 0.00 \\
\hline \#Plans & 377 & & & 377 & & & 377 & & & 377 & & \\
\hline \#Observations & 2315 & & & 2315 & & & 2315 & & & 2315 & & \\
\hline \multicolumn{13}{|c|}{ Panel B (the control variables are measured as annual averages) } \\
\hline C & -2.056 & 0.234 & 0.00 & -2.309 & 0.295 & 0.00 & -2.047 & 0.240 & 0.00 & -2.298 & 0.304 & 0.00 \\
\hline Emp & 0.196 & 0.071 & 0.01 & 0.251 & 0.083 & 0.00 & 0.193 & 0.072 & 0.01 & 0.247 & 0.084 & 0.00 \\
\hline Fees & 0.008 & 0.020 & 0.70 & -0.081 & 0.027 & 0.00 & 0.007 & 0.020 & 0.73 & -0.082 & 0.027 & 0.00 \\
\hline SizeMgFirm & 0.035 & 0.011 & 0.00 & 0.041 & 0.013 & 0.00 & 0.035 & 0.011 & 0.00 & 0.041 & 0.013 & 0.00 \\
\hline Var & 0.001 & 0.003 & 0.75 & 0.010 & 0.004 & 0.01 & 0.001 & 0.003 & 0.83 & 0.010 & 0.004 & 0.01 \\
\hline New & & & & & & & -0.031 & 0.114 & 0.79 & -0.049 & 0.124 & 0.69 \\
\hline Perf Initial & 0.351 & 0.094 & 0.00 & 0.277 & 0.119 & 0.02 & 0.352 & 0.094 & 0.00 & 0.278 & 0.119 & 0.02 \\
\hline Year Effects & & Yes & & & Yes & & & Yes & & & Yes & \\
\hline Family Effects & & Yes & & & Yes & & & Yes & & & Yes & \\
\hline R2 & 0.881 & & & 0.857 & & & 0.881 & & & 0.858 & & \\
\hline Wald & 42616 & & 0.00 & 41594 & & 0.00 & 42723 & & 0.00 & 42616 & & 0.00 \\
\hline \#Plans & 377 & & & 377 & & & 377 & & & 377 & & \\
\hline \#Observations & 2308 & & & 2308 & & & 2308 & & & 2308 & & \\
\hline
\end{tabular}

Results of the Panel Data estimation for employer-sponsored and individual plans. Coef is the coefficient estimate, and SE is the robust standard error. The dependent variable is Plan Performance (before fees) and Net Performance (after fees) proxied by the Sharpe Ratio. The independent variables are a dummy variable, Emp, which is equal to 1 in the case of employer-sponsored plans and 0 otherwise, total plan fees (management+custody fees) (Fees), Size of management firm (SizeMgFirm), proxied by its total assets under management, plan return variance (Var), a dummy variable, New, representing the first year of a pension plan, and the plan's baseline performance (Perflnitial, year 2007). In Panel A Fees,Var and SizeMgFirm are lagged by one period. In Panel B Fees,Var and SizeMgFirm are measured as annual averages. Fixed year effects and dummy variables representing the top families (average number of plans per year $>20$ ) are also included in the estimation. The table also shows the number of observations and number of Plans, the R2 and the Wald test. 
Table 9: Robustness Checks IV: Parasitic performance patterns.

\begin{tabular}{|c|c|c|c|c|c|c|c|c|c|c|c|c|}
\hline & \multicolumn{3}{|c|}{ Performance } & \multicolumn{3}{|c|}{ Net Performance } & \multicolumn{3}{|c|}{ Performance } & \multicolumn{3}{|c|}{ Net Performance } \\
\hline & Coef & SE & p-val & Coef & SE & p-val & Coef & SE & p-val & Coef & SE & p-val \\
\hline \multicolumn{13}{|c|}{ Panel A (the control variables are lagged by one period) } \\
\hline C & -1.775 & 0.200 & 0.00 & -1.988 & 0.247 & 0.00 & -1.765 & 0.208 & 0.00 & -1.972 & 0.261 & 0.00 \\
\hline Emp & 0.160 & 0.095 & 0.09 & 0.230 & 0.108 & 0.03 & 0.158 & 0.095 & 0.10 & 0.227 & 0.109 & 0.04 \\
\hline IBoth & -0.100 & 0.067 & 0.13 & -0.116 & 0.070 & 0.10 & -0.097 & 0.066 & 0.14 & -0.113 & 0.069 & 0.10 \\
\hline EBoth & 0.310 & 0.135 & 0.02 & 0.393 & 0.147 & 0.01 & 0.317 & 0.132 & 0.02 & 0.401 & 0.145 & 0.01 \\
\hline Fees & 0.007 & 0.020 & 0.71 & -0.061 & 0.026 & 0.02 & 0.007 & 0.020 & 0.74 & -0.063 & 0.026 & 0.02 \\
\hline SizeMgFirm & 0.021 & 0.010 & 0.03 & 0.023 & 0.011 & 0.04 & 0.021 & 0.010 & 0.03 & 0.023 & 0.011 & 0.05 \\
\hline Var & 0.001 & 0.003 & 0.85 & 0.009 & 0.004 & 0.01 & 0.000 & 0.003 & 0.94 & 0.009 & 0.004 & 0.02 \\
\hline New & & & & & & & -0.031 & 0.114 & 0.79 & -0.051 & 0.124 & 0.68 \\
\hline Perf Initial & 0.351 & 0.094 & 0.00 & 0.276 & 0.119 & 0.02 & 0.351 & 0.094 & 0.00 & 0.276 & 0.120 & 0.02 \\
\hline Year Effects & & Yes & & & Yes & & & Yes & & & Yes & \\
\hline Family Effects & & Yes & & & Yes & & & Yes & & & Yes & \\
\hline IBoth $=E$ Both & & & & & & & & & & & & \\
\hline$\chi^{2}(1)$ & 10.16 & & 0.00 & 13.42 & & 0.00 & 10.96 & & 0.00 & 14.27 & & 0.00 \\
\hline R2 & 0.881 & & & 0.857 & & & 0.881 & & & 0.857 & & \\
\hline Wald & 44570 & & 0.00 & 43146 & & 0.00 & 44643 & & 0.00 & 44204 & & \\
\hline \#Plans & 377 & & & 377 & & & 377 & & & 377 & & \\
\hline \#Observations & 2308 & & & 2308 & & & 2308 & & & 2308 & & \\
\hline \multicolumn{13}{|c|}{ Panel B (the control variables are measured as annual averages) } \\
\hline C & -2.005 & 0.219 & 0.00 & -2.240 & 0.271 & 0.00 & -1.993 & 0.224 & 0.00 & -2.226 & 0.280 & 0.00 \\
\hline Emp & 0.161 & 0.091 & 0.08 & 0.215 & 0.103 & 0.04 & 0.159 & 0.091 & 0.08 & 0.212 & 0.103 & 0.04 \\
\hline IBoth & -0.099 & 0.066 & 0.13 & -0.110 & 0.067 & 0.10 & -0.096 & 0.065 & 0.14 & -0.114 & 0.069 & 0.10 \\
\hline EBoth & 0.271 & 0.124 & 0.03 & 0.354 & 0.127 & 0.01 & 0.278 & 0.121 & 0.02 & 0.401 & 0.144 & 0.01 \\
\hline Fees & 0.009 & 0.020 & 0.65 & -0.079 & 0.028 & 0.00 & 0.008 & 0.020 & 0.68 & -0.081 & 0.027 & 0.00 \\
\hline SizeMgFirm & 0.033 & 0.010 & 0.00 & 0.038 & 0.012 & 0.00 & 0.033 & 0.010 & 0.00 & 0.037 & 0.012 & 0.00 \\
\hline Var & 0.000 & 0.003 & 0.86 & 0.009 & 0.004 & 0.01 & 0.000 & 0.003 & 0.96 & 0.009 & 0.004 & 0.02 \\
\hline New & & & & & & & -0.034 & 0.114 & 0.77 & -0.053 & 0.124 & 0.67 \\
\hline PerfInitial & 0.350 & 0.093 & 0.00 & 0.276 & 0.119 & 0.02 & 0.350 & 0.094 & 0.00 & 0.276 & 0.119 & 0.02 \\
\hline Year Effects & & Yes & & & Yes & & & Yes & & & Yes & \\
\hline Family Effects & & Yes & & & Yes & & & Yes & & & Yes & \\
\hline IBoth=EBoth & & & & & & & & & & & & \\
\hline$\chi^{2}(1)$ & 10.31 & & 0.00 & 16.32 & & 0.00 & 11.17 & & 0.00 & 17.53 & & 0.00 \\
\hline R2 & 0.881 & & & 0.858 & & & 0.881 & & & 0.858 & & \\
\hline Wald & 46165 & & 0.00 & 45098 & & 0.00 & 46386 & & 0.00 & 46684 & & \\
\hline \#Plans & 377 & & & 377 & & & 377 & & & 377 & & \\
\hline \#Observations & 2308 & & & 2308 & & & 2308 & & & 2308 & & \\
\hline
\end{tabular}

Results of the Panel Data estimation for employer-sponsored and individual plans. Coef is the coefficient estimate, and SE is the robust standard error of the estimate. The dependent variable is Plan Performance (before fees) and Net Performance (after fees) proxied by the Sharpe Ratio. The independent variables are a dummy variable, Emp, which is equal to 1 in the case of employer-sponsored plans and 0 otherwise, IBoth, which is equal to 1 in the case of individual plans managed by a firm that also manages employer-sponsored plans and 0 otherwise, EBoth which is equal to 1 in the case of employer-sponsored plans managed by a firm that also manages individual plans and 0 otherwise, total plan fees (management+custody fees) (Fees), Size of management firm (SizeMgFirm), proxied by its total assets 
under management (SizeMgFirm), plan return variance (Var), a dummy variable, New, representing the first year of a pension plan, and the plan's baseline performance (PerfInitial, year 2007). In Panel A Fees, Var and SizeMgFirm are lagged by one period. In Panel B Fees, Var and SizeMgFirm are measured as annual averages. Fixed year effects and dummy variables representing the top families (average number of plans per year>20) are also included in the estimation. The table also shows the number of observations and number of plans, the R2 and the Wald tests. 
Table 10: Robustness Checks V: CLAD estimation

\begin{tabular}{lrrrr}
\hline & \multicolumn{1}{l}{ Coef } & \multicolumn{1}{c}{ SE } & \multicolumn{1}{c}{ Coef } & \multicolumn{1}{l}{ SE } \\
\hline C & 1.544 & $0.32 *$ & 1.149 & $0.28 *$ \\
Emp & -1.414 & $0.11 *$ & -0.662 & $0.15 *$ \\
IBoth & & & 0.141 & $0.07 *$ \\
EBoth & & & -0.668 & $0.17 *$ \\
Perf & 0.052 & 0.03 & 0.062 & $0.02 *$ \\
Var & 0.004 & $0 *$ & 0.005 & $0 *$ \\
New & -0.077 & 0.08 & -0.074 & 0.07 \\
SizeMgFirm & 0.025 & 0 & 0.043 & $0.01 *$ \\
Year Effects & Yes & & Yes & \\
Family Effects & Yes & & Yes & \\
\hline K and N & 16 & 2309 & 18 & 2309 \\
Pseudo R2 & 0.598 & & 0.592 & \\
\hline
\end{tabular}

The results of the estimation of the CLAD Model 3 for employer-sponsored and individual plans. Coef is the coefficient estimation, and SE is the standard error of this estimation. The dependent variable is total plan fees (management+custody) expressed in \% (Fees). The independent variables are a dummy variable, Emp, which is equal to 1 in the case of employer-sponsored plans and 0 otherwise, IBoth which is equal to 1 in the case of individual plans managed by a firm that also manages employer-sponsored plans and 0 otherwise, EBoth, which is equal to 1 in the case of employer-sponsored plans managed by a firm that also manages individual plans and 0 otherwise, Plan Performance (Perf), proxied by the Sharpe Ratio, plan return variance (Var), a dummy variable, New, representing the first year of a pension plan, Size of Management firm (SizeMgFirm), proxied by its total assets under management, and the lag of total fees (Feeslag). Perf, Var and SizeMgFirm are measured as annual averages. Fixed year effects and dummy variables representing the top families (average number of plans per year>20) are also included in the estimation. The table also shows the number of observations $(\mathrm{N})$ and the pseudo- $\mathrm{R} 2$ for the model tested. * denotes the $5 \%$ level of significance 


\section{Table 11: Robustness Checks VI: Other control variables}

\begin{tabular}{|c|c|c|c|c|c|c|}
\hline & Coef & SE & & Coef & SE & \\
\hline C & 1.976 & 0.13 & * & 1.925 & 0.13 & * \\
\hline Emp & -1.008 & 0.09 & * & -0.587 & 0.12 & * \\
\hline IBoth & & & & 0.160 & 0.07 & * \\
\hline EBoth & & & & -0.332 & 0.15 & * \\
\hline Perf & 0.004 & 0.03 & & 0.007 & 0.02 & \\
\hline Var & 0.009 & 0.00 & * & 0.009 & 0.00 & * \\
\hline New & -0.110 & 0.09 & & -0.104 & 0.09 & \\
\hline SPlan & 0.045 & 0.01 & * & 0.046 & 0.01 & * \\
\hline AvgInv & -0.115 & 0.01 & * & -0.113 & 0.01 & * \\
\hline Year Effects & Yes & & & Yes & & \\
\hline Family Effects & Yes & & & Yes & & \\
\hline $\mathrm{K}$ and $\mathrm{N}$ & 17 & 2275 & & 19 & 2274 & \\
\hline $\mathrm{F}(\mathrm{K}, \mathrm{N})$ & 401.16 & 0.00 & & 268.17 & 0.00 & \\
\hline
\end{tabular}

Results of the estimation of the Tobit model for employer-sponsored and individual plans. Coef is the coefficient estimate, and SE is the robust standard error. The dependent variable is total plan fees (management+custody) expressed in \% (Fees). The independent variables are a dummy variable, Emp, which is equal to 1 in the case of employer-sponsored plans and 0 otherwise, IBoth which is equal to 1 in the case of individual plans managed by a firm that also manages employer-sponsored plans and 0 otherwise, EBoth, which is equal to 1 in the case of employer-sponsored plans managed by a firm that also manages individual plans and 0 otherwise, Plan Performance (Perf), proxied by the Sharpe Ratio, plan return variance (Var), a dummy variable, New, representing the first year of a pension plan,)the log of plan assets in Euros (SPlan), the log of average investment size per participant of the plan (AvgInv), and the lag of total fees (Feeslag). Perf, Var and SPlan and AvgInv are measured as annual averages. Fixed year effects and dummy variables representing the top families (average number of plans per year $>20$ ) are also included in the estimation. The table also shows the number of observations $(\mathrm{N})$ and the F-test for the model tested $(\mathrm{F}(\mathrm{K}, \mathrm{N})$. * denotes the $5 \%$ level of significance. 